\title{
1 2,4-Alkadienal trapping by phenolics
}

2 Francisco J. Hidalgo and Rosario Zamora *

3 Instituto de la Grasa, Consejo Superior de Investigaciones Científicas, Carretera de

$4 \quad$ Utrera km 1, Campus Universitario - Edificio 46, 41013-Seville, Spain

5

$6 \quad * \quad$ Corresponding author. Tel.: +34 954611 550; fax: +34 954616 790. E-mail

7 address: rzamora@ig.csic.es (R. Zamora)

8

$9 \quad$ Food Chem. 263 (2018) 89-95 
11 Phenolics can trap lipid-derived reactive carbonyls as a protective function that

12 diminishes the broadcasting of the lipid oxidative damage to food macromolecules. In

13 an attempt to clarify the trapping of 2,4-alkadienals by phenolics, this study analyzes the

14 reactions of 2,4-hexadienal, 2,4-heptadienal, and 2,4-decadienal with 2-

15 methylresorcinol. These reactions produced (E)-4-(alk-1-en-1-yl)-8-methyl-2,7-

16 bis(prop-1-en-2-yloxy)chromanes, which were isolated and characterized by 1D and 2D

17 NMR and MS. Carbonyl-phenol adduct formation was favored at $\mathrm{pH}>7$ and moderated

18 temperatures $\left(25-80{ }^{\circ} \mathrm{C}\right)$. Adducts were quantified and shown to be produced as a

19 mixture of diastereomers. Diastereomers $2 R, 4 S$ plus $2 S, 4 R$ were formed to a higher

20 extent than diastereomers $2 R, 4 R$ plus $2 S, 4 S$ under the different conditions assayed,

21 although activation energies $\left(E_{a}\right)$ for the formation of all of them was mostly the same

$22\left(\sim 62 \mathrm{~kJ} \cdot \mathrm{mol}^{-1}\right)$. These results show that phenolics can trap 2,4-alkadienals and provide

23 the basis for the later detection of the formed adducts in food products.

24 Keywords:

25 Alka-2,4-dienals; Carbonyl-phenol reactions; Lipid oxidation; Maillard reaction;

26 Reactive carbonyls

27 Chemical compounds studied in this article:

28 (2E,4E)-Deca-2,4-dienal (PubChem ID: 5283349); 2-Methylresorcinol (PubChem ID:

29 11843); (2E,4E)-Hepta-2,4-dienal (PubChem ID: 5283321); (2E,4E)-Hexa-2,4-dienal

30 (PubChem ID: 637564) 


\section{Introduction}

Lipid oxidation is a common source of reactive carbonyls in foods (Bastos, Costa, \& Pereira, 2017; Concepcion et al., 2018). Once formed, these compounds have a great relevance in food quality and safety because of their sensory properties (Rendon, Salva, \& Bragagnolo, 2014), their ability to modify food macromolecules (Lorenzo, Pateiro, Fontan, \& Carballo, 2014), and their tendency to produce nonenzymatic browning (Potes, Kerry, \& Roos, 2013). Because they are electrophiles, these carbonyls react easily with the nucleophiles present in foods. Among them, a common sink for the most reactive lipid-derived reactive carbonyls is their reaction with amine compounds, including amines, amino acids, aminophospholipids, and proteins (Zamora \& Hidalgo, 2005). In addition, phenolics have also been shown to exhibit enough nucleophilicity to act as an alternative sink for lipid-derived reactive carbonyls (Zamora \& Hidalgo, 2016). This reaction produces many different carbonyl-phenol adducts, whose structures are related to the structures of the lipid-derived reactive carbonyls involved. At present, the carbonyl-phenol adducts formed in the reaction of phenolics with alkanals (Hidalgo, Aguilar, \& Zamora, 2017), 2-alkenals (Hidalgo \& Zamora, 2014), 4-oxo-2-alkenals (Hidalgo, Aguilar, \& Zamora, 2018), and 4,5-epoxy-2-alkenals (Zamora, Aguilar, \& Hidalgo, 2017) have been isolated and characterized. Furthermore, some of these adducts have been detected in food products (Zamora, Aguilar, Granvogl, \& Hidalgo, 2016). In addition to these compounds, 2,4-alkadienals are also major lipid-derived reactive carbonyls produced as a consequence of the lipid oxidation process (Chen, Cao, Li, Sun,

54 Wang, Li, \& Liu, 2017). Moreover, they have been shown to be involved in the formation of both foodborne toxicants and food flavors. Among foodborne toxicants, their contribution to the formation of acrylamide (Hidalgo, Delgado, \& Zamora, 2009), 
57 biogenic amines (Hidalgo, Navarro, Delgado, \& Zamora, 2013), and heterocyclic

58 aromatic amines (Zamora, Alcon, \& Hidalgo, 2012) has been described. In addition,

59 they contribute to the formation of Strecker aldehydes among other food flavors

60 (Zamora, Gallardo, \& Hidalgo, 2007; Zamora, Navarro, Aguilar, \& Hidalgo, 2015).

61 In an attempt to determine the ability of phenolics to trap 2,4-alkadienals, to identify

62 the structures of the produced adducts, and to study the reaction conditions that favor

63 carbonyl-phenol adduct formation, this manuscript describes the reaction of 2,4-

64 alkadienals (2,4-hexadienal, 2,4-heptadienal, and 2,4-decadienal) with 2-

methylresorcinol. 2-Methylresorcinol was employed as a model phenolic compound because of its small molecular weight, which facilitates the characterization of the

67 produced adducts, and its high carbonyl trapping potential (Hidalgo, Navarro, \&

68 Zamora, 2018; Salazar, Arambula-Villa, Hidalgo, \& Zamora, 2014).

\section{2. Materials and methods}

70

71

\subsection{Materials}

Three 2,4-alkadienals were employed in this study: 2,4-heptadienal, which is the oxidation product of $\omega 3$ fatty acyl chains; 2,4-decadienal, which is the oxidation product of $\omega 6$ fatty acyl chains; and 2,4-hexadienal, which has a small side chain and helped in the characterization of the structures of the obtained adducts. These compounds, as well as other chemicals employed in these studies, were purchased from Sigma-Aldrich (St. Louis, MO), Merck (Darmstadt, Germany) or Fluka (Buchs, Switzerland), and were of the highest available grade.

\subsection{Formation of carbonyl-phenol adducts in the reaction of alkadienals and phenolic} compounds 
81 (30 $\mu \mathrm{mol}$ of each in $500 \mu \mathrm{L}$ of $0.3 \mathrm{M}$ buffer) were heated at $60^{\circ} \mathrm{C}$ for up to $24 \mathrm{~h}$ under

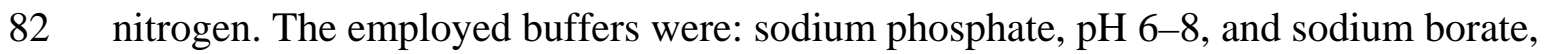

$83 \mathrm{pH}$ 8-10. At the end of the heating, reactions were stopped by cooling at room

84 temperature for 10 min and removing the unreacted aldehyde by evaporation of the reaction to dryness using a flow of nitrogen. This evaporation was facilitated by addition of $1.2 \mathrm{~mL}$ of ethanol. Dried samples were then treated with $30 \mu \mathrm{L}$ of internal standard (a solution of $36.64 \mathrm{mg}$ of cis-3-nonen-1-ol in $5 \mathrm{~mL}$ of anhydrous pyridine), and acetylated with $1 \mathrm{~mL}$ of anhydrous pyridine and $0.5 \mathrm{~mL}$ of acetic anhydride. After $20 \mathrm{~h}$ at room temperature $\left(22^{\circ} \mathrm{C}\right), 2 \mathrm{~mL}$ of dichloromethane and $2 \mathrm{~mL}$ of water were added. Layers were separated and the organic layer was washed successively with $2 \mathrm{~mL}$ of $5 \%$ hydrochloric acid (four times), and $2 \mathrm{~mL}$ of water. After centrifugation, the organic layer was studied by gas chromatography coupled to mass spectrometry (GC93 MS).

For preparative purposes, the reaction was carried out analogously but mixtures containing $2.5 \mathrm{mmol}$ of each reactant were heated in $4 \mathrm{~mL}$ of $0.3 \mathrm{M}$ sodium phosphate buffer, $\mathrm{pH}$ 8. Acetylation was carried out with $80 \mathrm{~mL}$ of anhydrous pyridine and $40 \mathrm{~mL}$

97 of acetic anhydride under the same reaction conditions described above. Acetylated

98 reaction mixtures were fractionated by column chromatography on silica gel 60 using

99 hexane:diethyl mixtures as eluent. Separation was controlled by GC-MS. The structures

100 of the adducts isolated and characterized in the assayed reactions are collected in Fig. 1.

101 2.2.1. Compounds isolated and characterized in the reaction of 2,4-heptadienal and 2-

102 methylresorcinol

103 Reactions were carried out in phosphate buffer, $\mathrm{pH}$ 8. As observed in the total ion 104 chromatogram of the reaction mixture (Fig. 1 ), two main adducts $(\mathbf{1}, \mathbf{2})$ were formed, 
which were isolated and characterized. Both compounds were identified as two isomers

106 of (E)-4-(but-1-en-1-yl)-8-methyl-2,7-bis(prop-1-en-2-yloxy)chromane.

107 Spectroscopic and spectrometric data of compound $1 .{ }^{1} \mathrm{H} \mathrm{NMR}\left(\mathrm{CDCl}_{3}\right): \delta$ 1.06t $(3 \mathrm{H}$, $108 J=7.5 \mathrm{~Hz}, \mathrm{H} 4$ '), $1.91 \mathrm{ddd}(1 \mathrm{H}, J=2.6 \mathrm{~Hz}, J=12.1 \mathrm{~Hz}, J=13.9 \mathrm{~Hz}, \mathrm{H3a}), 2.02 \mathrm{~s}(3 \mathrm{H}$,

$\left.109 \mathrm{CH}_{3} \mathrm{C} 8\right), 2.11 \mathrm{~s}\left(3 \mathrm{H}, \mathrm{CH}_{3} \mathrm{CO}\right), 2.11 \mathrm{~m}(3 \mathrm{H}, \mathrm{H} 3$ ' and $\mathrm{H3b}), 2.33 \mathrm{~s}\left(3 \mathrm{H}, \mathrm{CH}_{3} \mathrm{CO}\right), 3.59$ ddd $110(1 \mathrm{H}, J=5.7 \mathrm{~Hz}, J=8.9 \mathrm{~Hz}, J=12.1 \mathrm{~Hz}, \mathrm{H} 4), 5.34 \mathrm{ddt}(1 \mathrm{H}, J=1.5 \mathrm{~Hz}, J=8.9 \mathrm{~Hz}, J=$ $11115.2 \mathrm{~Hz}, \mathrm{H1}$ '), $5.77 \mathrm{dt}(1 \mathrm{H}, J=6.4 \mathrm{~Hz}, J=15.2 \mathrm{~Hz}, \mathrm{H} 2$ '), $6.57 \mathrm{t}(1 \mathrm{H}, J=2.6 \mathrm{~Hz}, \mathrm{H} 2)$, 112 6.65d (1H, $J=8.4 \mathrm{~Hz}, \mathrm{H} 6)$, and 7.05d $(1 \mathrm{H}, J=8.4 \mathrm{~Hz}, \mathrm{H} 5) .{ }^{13} \mathrm{C} \mathrm{NMR}\left(\mathrm{CDCl}_{3}\right): \delta 9.21$

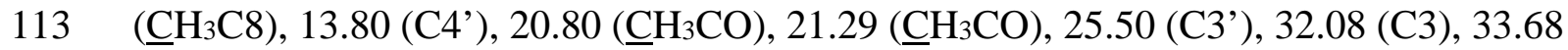
114 (C4), 89.90 (C2), 114.50 (C6), 118.66 (C8), 121.99 (C4a), 125.88 (C5), 129.81 (C1’), 115 135.73 (C2'), 148.53 (C7), 149.71 (C8a), 169.41 (CO), and 169.73 (CO). MS, m/z (\%, ion structure): $318\left(0.2, \mathrm{M}^{+}\right), 276\left(0.2, \mathrm{M}^{+}-\mathrm{CH}_{2} \mathrm{CO}\right), 258$ (39, $\left.\mathrm{M}^{+}-\mathrm{CH}_{3} \mathrm{COOH}\right), 234$

117 (5, $\left.276-\mathrm{CH}_{2} \mathrm{CO}\right), 229$ (26, $\left.258-\mathrm{CH}_{3} \mathrm{CH}_{2}\right), 216$ (65, $\left.258-\mathrm{CH}_{2} \mathrm{CO}\right), 205$ (15, $234-$ $118 \mathrm{CHO}), 191$ (51, $\left.234-\mathrm{CH}_{2} \mathrm{CHO}\right), 187\left(100,216-\mathrm{CH}_{3} \mathrm{CH}_{2}\right)$, and 161 (37, $216-$ $\left.119 \mathrm{CH}_{3} \mathrm{CH}_{2} \mathrm{CH}=\mathrm{CH}\right)$.

120 Spectroscopic and spectrometric data of compound 2. ${ }^{1} \mathrm{H} \mathrm{NMR}\left(\mathrm{CDCl}_{3}\right): \delta 1.04 \mathrm{t}(3 \mathrm{H}$, $\left.121 J=7.5 \mathrm{~Hz}, \mathrm{H} 4^{\prime}\right), 2.02 \mathrm{~m}(1 \mathrm{H}, \mathrm{H} 3 \mathrm{~b}), 2.03 \mathrm{~s}\left(3 \mathrm{H}, \mathrm{CH}_{3} \mathrm{C} 8\right), 2.11 \mathrm{~m}(2 \mathrm{H}, \mathrm{H} 3$ '), 2.13s (3H, $\left.122 \mathrm{CH}_{3} \mathrm{CO}\right), 2.27 \mathrm{ddd}(1 \mathrm{H}, J=2.9 \mathrm{~Hz}, J=6.4 \mathrm{~Hz}, J=13.7 \mathrm{~Hz}, \mathrm{H} 3 \mathrm{a}), 2.33 \mathrm{~s}\left(3 \mathrm{H}, \mathrm{CH}_{3} \mathrm{CO}\right)$, 1233.50 q,br (1H, $J=7.0 \mathrm{~Hz}, \mathrm{H} 4), 5.55$ ddt (1H, $\left.J=1.4 \mathrm{~Hz}, J=8.7 \mathrm{~Hz}, J=15.2 \mathrm{~Hz}, \mathrm{H} 1^{\prime}\right)$, $1245.69 \mathrm{dt}(1 \mathrm{H}, J=6.2 \mathrm{~Hz}, J=15.2 \mathrm{~Hz}, \mathrm{H} 2$ '), 6.49dd (1H, $J=2.9 \mathrm{~Hz}, J=6.1 \mathrm{~Hz}, \mathrm{H} 2)$, 125 6.65d $(1 \mathrm{H}, J=8.4 \mathrm{~Hz}, \mathrm{H} 6)$, and 6.99d $(1 \mathrm{H}, J=8.4 \mathrm{~Hz}, \mathrm{H} 5) .{ }^{13} \mathrm{C} \mathrm{NMR}\left(\mathrm{CDCl}_{3}\right): \delta 9.17$

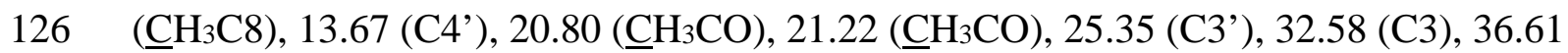
127 (C4), 91.43 (C2), 114.66 (C6), 118.82 (C8), 121.77 (C4a), 126.53 (C5), 131.29 (C1'), 128 133.78 (C2'), 148.50 (C7), 150.31 (C8a), 169.36 (CO), and 169.52 (CO). MS, m/z (\%, 129 ion structure): $318\left(32, \mathrm{M}^{+}\right), 276$ (312, $\left.\mathrm{M}^{+}-\mathrm{CH}_{2} \mathrm{CO}\right), 258$ (3, $\left.\mathrm{M}^{+}-\mathrm{CH}_{3} \mathrm{COOH}\right), 234$ 
130 (20, $\left.276-\mathrm{CH}_{2} \mathrm{CO}\right), 229$ (13, $\left.258-\mathrm{CH}_{3} \mathrm{CH}_{2}\right), 216$ (56, $\left.258-\mathrm{CH}_{2} \mathrm{CO}\right), 205$ (28, $234-$

131 CHO), 191 (89, $\left.234-\mathrm{CH}_{2} \mathrm{CHO}\right), 187$ (100, $\left.216-\mathrm{CH}_{3} \mathrm{CH}_{2}\right)$, and 161 (55, $216-$

$\left.132 \mathrm{CH}_{3} \mathrm{CH}_{2} \mathrm{CH}=\mathrm{CH}\right)$.

133 2.2.2. Compounds isolated and characterized in the reaction of 2,4-decadienal and 2-

134 methylresorcinol

135 Reactions were carried out in phosphate buffer, $\mathrm{pH} \mathrm{8,} \mathrm{and} \mathrm{the} \mathrm{total} \mathrm{ion} \mathrm{chromatogram}$

136 of the reaction mixture (data not shown) also showed two main adducts $(3,4)$. These

137 compounds were isolated and characterized as two isomers of (E)-4-(hept-1-en-1-yl)-8-

138 methyl-2,7-bis(prop-1-en-2-yloxy)chromane.

139 Spectroscopic and spectrometric data of compound 3. ${ }^{1} \mathrm{H} \mathrm{NMR}\left(\mathrm{CDCl}_{3}\right)$ : $\delta$ 0.93t $(3 \mathrm{H}$, $140 J=7.0$ Hz, H7'), 1.28m (4H, H4' and H6'), 1.35m (2H, H5’), 1.43m (2H, H3'), 1.91 141 ddd $(1 \mathrm{H}, J=2.5 \mathrm{~Hz}, J=12.1 \mathrm{~Hz}, J=13.9 \mathrm{~Hz}, \mathrm{H3a}), 2.03 \mathrm{~s}(3 \mathrm{H}, \mathrm{CH} \mathrm{C} 8), 2.11 \mathrm{~s}(3 \mathrm{H}$, $\left.142 \mathrm{CH}_{3} \mathrm{CO}\right), 2.11 \mathrm{~m}(1 \mathrm{H}, \mathrm{H} 3 \mathrm{~b}), 2.33 \mathrm{~s}\left(3 \mathrm{H}, \mathrm{CH}_{3} \mathrm{CO}\right), 3.59$ ddd $(1 \mathrm{H}, J=5.5 \mathrm{~Hz}, J=8.8 \mathrm{~Hz}, J$ $143=12.1 \mathrm{~Hz}, \mathrm{H} 4), 5.34 \mathrm{ddt}\left(1 \mathrm{H}, J=1.4 \mathrm{~Hz}, J=8.8 \mathrm{~Hz}, J=15.2 \mathrm{~Hz}, \mathrm{H} 1{ }^{\prime}\right), 5.72 \mathrm{dt}(1 \mathrm{H}, J=$ $1446.9 \mathrm{~Hz}, J=15.2 \mathrm{~Hz}, \mathrm{H2}$ '), 6.57t (1H, $J=2.5 \mathrm{~Hz}, \mathrm{H} 2), 6.65 \mathrm{~d}(1 \mathrm{H}, J=8.4 \mathrm{~Hz}, \mathrm{H} 6)$, and

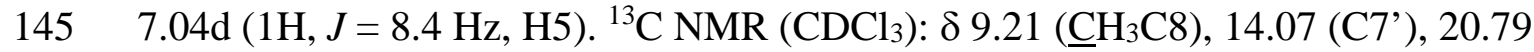

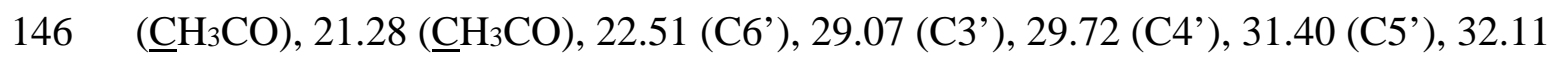
147 (C3), 33.77 (C4), 89.90 (C2), 114.50 (C6), 118.66 (C8), 121.98 (C4a), 125.90 (C5), 148130.75 (C1'), 134.28 (C2'), 148.53 (C7), 149.70 (C8a), 169.41 (CO), and 169.72 (CO). 149 MS, m/z (\%, ion structure): $360\left(0.4, \mathrm{M}^{+}\right), 318\left(1, \mathrm{M}^{+}-\mathrm{CH}_{2} \mathrm{CO}\right), 300\left(28, \mathrm{M}^{+}-\right.$ $\left.150 \mathrm{CH}_{3} \mathrm{COOH}\right), 276$ (2, $\left.318-\mathrm{CH}_{2} \mathrm{CO}\right), 258$ (37, $\left.300-\mathrm{CH}_{2} \mathrm{CO}\right), 233$ (18, $276-$ $\left.151 \mathrm{CH}_{2} \mathrm{CHO}\right), 229$ (42, $\left.258-\mathrm{CH}_{3} \mathrm{CH}_{2}\right), 187\left(100,258-\mathrm{CH}_{3} \mathrm{CH}_{2} \mathrm{CH}_{2} \mathrm{CH}_{2} \mathrm{CH}_{2}\right)$, and 161 (57, $\left.258-\mathrm{CH}_{3} \mathrm{CH}_{2} \mathrm{CH}_{2} \mathrm{CH}_{2} \mathrm{CH}_{2} \mathrm{CH}=\mathrm{CH}\right)$. 
Spectroscopic and spectrometric data of compound 4. ${ }^{1} \mathrm{H}$ NMR $\left(\mathrm{CDCl}_{3}\right): \delta 0.92 \mathrm{t}(3 \mathrm{H}$, $J=6.9 \mathrm{~Hz}, \mathrm{H} 7$ '), 1.28m (4H, H4' and H6'), 1.33m (2H, H5'), $1.43 q u(2 \mathrm{H}, J=7.2 \mathrm{~Hz}$, H3’), 2.02m (1H, H3b), 2.02s (3H, $\left.\mathrm{CH}_{3} \mathrm{C} 8\right), 2.13 \mathrm{~s}$ (3H, $\left.\mathrm{CH}_{3} \mathrm{CO}\right), 2.27$ ddd (1H, $J=3.0$ $\mathrm{Hz}, J=6.4 \mathrm{~Hz}, J=13.7 \mathrm{~Hz}, \mathrm{H3a}), 2.33 \mathrm{~s}\left(3 \mathrm{H}, \mathrm{CH}_{3} \mathrm{CO}\right), 3.52$ q,br $(1 \mathrm{H}, J=7.0 \mathrm{~Hz}, \mathrm{H} 4)$, 5.54 ddt $\left(1 \mathrm{H}, J=1.2 \mathrm{~Hz}, J=8.6 \mathrm{~Hz}, J=15.2 \mathrm{~Hz}, \mathrm{H} 1^{\prime}\right), 5.64 \mathrm{dt}(1 \mathrm{H}, J=6.6 \mathrm{~Hz}, J=$ $15.2 \mathrm{~Hz}, \mathrm{H2}$ '), 6.48dd (1H, $J=3.0 \mathrm{~Hz}, J=6.3 \mathrm{~Hz}, \mathrm{H} 2), 6.65 \mathrm{~d}(1 \mathrm{H}, J=8.4 \mathrm{~Hz}, \mathrm{H} 6)$, and 6.98d (1H, $J=8.4 \mathrm{~Hz}, \mathrm{H} 5) .{ }^{13} \mathrm{C}$ NMR $\left(\mathrm{CDCl}_{3}\right): \delta 9.17$ (年H3 $\left.\mathrm{C} 8\right), 14.06$ (C7’), 20.79

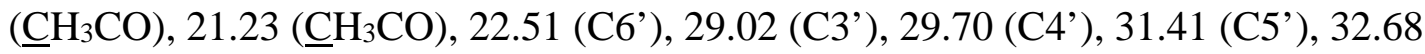
(C3), 36.76 (C4), 91.45 (C2), 114.66 (C6), 118.81 (C8), 121.80 (C4a), 126.49 (C5), 132.18 (C1'), 132.44 (C2’), 148.50 (C7), 150.33 (C8a), 169.37 (CO), and 169.53 (CO). MS, $m / z$ (\%, ion structure): 360 (12, $\left.\mathrm{M}^{+}\right), 318$ (12, $\left.\mathrm{M}^{+}-\mathrm{CH}_{2} \mathrm{CO}\right), 300$ (11, $\mathrm{M}^{+}-$ CH3 $\mathrm{COOH}), 276$ (5, $\left.318-\mathrm{CH}_{2} \mathrm{CO}\right), 258$ (24, $\left.300-\mathrm{CH}_{2} \mathrm{CO}\right), 233$ (20, $276-$

$\left.\mathrm{CH}_{2} \mathrm{CHO}\right), 229$ (31, $\left.258-\mathrm{CH}_{3} \mathrm{CH}_{2}\right), 215$ (27, $\left.258-\mathrm{CH}_{3} \mathrm{CH}_{2} \mathrm{CH}_{2}\right), 201$ (22, $258-$ $\left.\mathrm{CH}_{3} \mathrm{CH}_{2} \mathrm{CH}_{2} \mathrm{CH}_{2}\right), 187$ (100, $\left.258-\mathrm{CH}_{3} \mathrm{CH}_{2} \mathrm{CH}_{2} \mathrm{CH}_{2} \mathrm{CH}_{2}\right)$, and 161 (58, $258-$

\section{$\left.\mathrm{CH}_{3} \mathrm{CH}_{2} \mathrm{CH}_{2} \mathrm{CH}_{2} \mathrm{CH}_{2} \mathrm{CH}=\mathrm{CH}\right)$.}

2.2.3. Compounds isolated and characterized in the reaction of 2,4-hexadienal and 2methylresorcinol

8, and the total ion chromatogram of the reaction mixture (data not shown) also showed the formation of two adducts $(\mathbf{5 , 6})$. These adducts were isolated and characterized, and were identified as two isomers of (E)-8-methyl-4-(prop-1-en-1-yl)-2,7-bis(prop-1-en-2yloxy)chromane. (3H, $\left.J=1.6 \mathrm{~Hz}, J=6.4 \mathrm{~Hz}, \mathrm{H} 3^{\prime}\right), 1.91 \mathrm{ddd}(1 \mathrm{H}, J=2.7 \mathrm{~Hz}, J=12.0 \mathrm{~Hz}, J=14.1 \mathrm{~Hz}$, H3a), 2.02s (3H, $\left.\mathrm{CH}_{3} \mathrm{C} 8\right), 2.08 \mathrm{ddd}(1 \mathrm{H}, J=2.7 \mathrm{~Hz}, J=5.6 \mathrm{~Hz}, J=14.1 \mathrm{~Hz}, \mathrm{H3b})$, 
178

179

180

181

182

183

184

185

186

187

188

189

190

191

192

193

194

195

196

197

198

199

200

201

2.10s (3H, $\left.\mathrm{CH}_{3} \mathrm{CO}\right), 2.33 \mathrm{~s}\left(3 \mathrm{H}, \mathrm{CH}_{3} \mathrm{CO}\right), 3.60 \mathrm{ddd}(1 \mathrm{H}, J=5.6 \mathrm{~Hz}, J=8.9 \mathrm{~Hz}, J=12.0$

Hz, H4), 5.37 ddq (1H, $\left.J=1.6 \mathrm{~Hz}, J=8.9 \mathrm{~Hz}, J=15.0 \mathrm{~Hz}, \mathrm{H} 1^{\prime}\right), 5.73 \mathrm{dq}(1 \mathrm{H}, J=6.4$ $\left.\mathrm{Hz}, J=15.0 \mathrm{~Hz}, \mathrm{H} 2{ }^{\prime}\right), 6.57 \mathrm{t}(1 \mathrm{H}, J=2.7 \mathrm{~Hz}, \mathrm{H} 2), 6.65 \mathrm{~d}(1 \mathrm{H}, J=8.4 \mathrm{~Hz}, \mathrm{H} 6)$, and 7.04d (1H, $J=8.4 \mathrm{~Hz}, \mathrm{H} 5) .{ }^{13} \mathrm{C} \mathrm{NMR}\left(\mathrm{CDCl}_{3}\right): \delta 9.20$ (年H3C8), 17.88 (C3’), 20.79

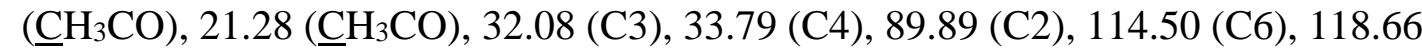
(C8), 121.92 (C4a), 125.92 (C5), 128.55 (C2’), 132.06 (C1’), 148.54 (C7), 149.71 (C8a), 169.40 (CO), and 169.72 (CO). MS, m/z (\%, ion structure): 304 (1, M ${ }^{+}$), 262 (1, $\left.\mathrm{M}^{+}-\mathrm{CH}_{2} \mathrm{CO}\right), 244$ (45, $\left.\mathrm{M}^{+}-\mathrm{CH}_{3} \mathrm{COOH}\right), 229$ (10, $\left.244-\mathrm{CH}_{3}\right), 220$ (7, $\left.262-\mathrm{CH}_{2} \mathrm{CO}\right)$, 202 (100, $\left.244-\mathrm{CH}_{2} \mathrm{CO}\right), 187$ (91, $\left.202-\mathrm{CH}_{3}\right), 177$ (64, $\left.220-\mathrm{CH}_{2} \mathrm{CHO}\right)$, and 161 (41, $\left.202-\mathrm{CH}_{3} \mathrm{CH}=\mathrm{CH}\right)$.

Spectroscopic and spectrometric data of compound 6. ${ }^{1} \mathrm{H}$ NMR $\left(\mathrm{CDCl}_{3}\right): \delta 1.74 \mathrm{dd}$ (3H, $J=1.1 \mathrm{~Hz}, J=6.1 \mathrm{~Hz}, \mathrm{H} 3$ '), 2.02m (1H, H3b), 2.02s (3H, $\left.\mathrm{CH}_{3} \mathrm{C} 8\right), 2.13 \mathrm{~s}(3 \mathrm{H}$, $\mathrm{CH}_{3} \mathrm{CO}$ ), 2.26 ddd (1H, $\left.J=2.9 \mathrm{~Hz}, J=6.5 \mathrm{~Hz}, J=13.7 \mathrm{~Hz}, \mathrm{H3a}\right), 2.33 \mathrm{~s}\left(3 \mathrm{H}, \mathrm{CH}_{3} \mathrm{CO}\right)$, 3.52 q,br (1H, $J=7.2 \mathrm{~Hz}, \mathrm{H} 4), 5.57 \mathrm{ddq}\left(1 \mathrm{H}, J=1.1 \mathrm{~Hz}, J=8.3 \mathrm{~Hz}, J=15.1 \mathrm{~Hz}, \mathrm{H} 1^{\prime}\right)$, $5.64 \mathrm{dq}(1 \mathrm{H}, J=6.1 \mathrm{~Hz}, J=15.1 \mathrm{~Hz}, \mathrm{H} 2$ '), $6.48 \mathrm{dd}(1 \mathrm{H}, J=2.9 \mathrm{~Hz}, J=6.1 \mathrm{~Hz}, \mathrm{H} 2)$, 6.65d (1H, $J=8.4 \mathrm{~Hz}, \mathrm{H} 6)$, and $6.98 \mathrm{~d}(1 \mathrm{H}, J=8.4 \mathrm{~Hz}, \mathrm{H} 5) .{ }^{13} \mathrm{C} \mathrm{NMR}\left(\mathrm{CDCl}_{3}\right): \delta 9.17$

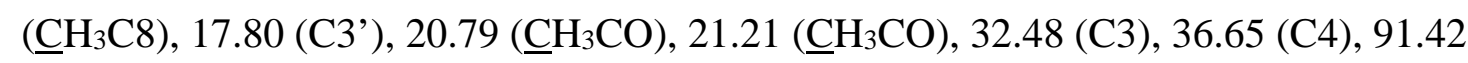
(C2), 114.67 (C6), 118.83 (C8), 121.68 (C4a), 126.54 (C5), 126.69 (C2’), 133.53 (C1’), 148.52 (C7), 150.30 (C8a), 169.34 (CO), and 169.52 (CO). MS, m/z (\%, ion structure): $304\left(35, \mathrm{M}^{+}\right), 262$ (35, $\left.\mathrm{M}^{+}-\mathrm{CH}_{2} \mathrm{CO}\right), 244$ (5, $\left.\mathrm{M}^{+}-\mathrm{CH}_{3} \mathrm{COOH}\right), 229$ (5, $\left.244-\mathrm{CH}_{3}\right)$, 220 (22, 262 - $\left.\mathrm{CH}_{2} \mathrm{CO}\right), 202$ (86, 244 - $\left.\mathrm{CH}_{2} \mathrm{CO}\right), 201$ (23, 220 - CHO), 187 (84, 202 $\left.\mathrm{CH}_{3}\right), 177$ (100, $\left.220-\mathrm{CH}_{2} \mathrm{CHO}\right)$, and 161 (54, $\left.202-\mathrm{CH}_{3} \mathrm{CH}=\mathrm{CH}\right)$.

\subsection{GC-MS analyses}

GC-MS analyses were carried out as described previously (Zamora et al., 2017). 


\subsection{Alkadienal-phenol adduct determination}

203 Formed adducts were determined by GC-MS. These compounds were quantified by

204 preparing standard curves of the isolated adducts. Six concentration levels were used.

205 Adduct content was directly proportional to adduct/internal standard area ratio $(r>0.99$,

$206 p<0.001)$. RSD was always $<10 \%$.

\subsection{NMR spectroscopy}

1D and 2D NMR spectra were obtained in a Bruker Advance III spectrometer operating at $500 \mathrm{MHz}$ for protons. Experiments were performed at $24{ }^{\circ} \mathrm{C}$ and acquisition parameters were described previously (Zamora et al., 2016).

\subsection{Statistical analysis}

All quantitative data are mean \pm SD values of, at least, three independent experiments. Analysis of variance was employed to compare different groups. When $F$

214 values were significantly different, group differences were evaluated by the Tukey test

215 (Snedecor \& Cochran, 1980). Statistical comparisons were carried out using Origin ${ }^{\circledR}$ v.

2167.0 (OriginLab Corporation, Northampton, MA). The significance level is $p<0.05$

217 unless otherwise indicated.

\section{3. Results}

3.1. Characterization of the adducts produced in the reaction between alkadienals and phenolic compounds

As observed in Fig. 1, the reaction between 2,4-heptadienal and 2-methylresorcinol

222 produced two main reaction products (compounds $\mathbf{1}$ and 2). Analogous results were

223 obtained when the reaction was carried out by using either 2,4-decadienal or 2,4-

224 hexadienal (data not shown). Both compounds exhibited similar NMR spectra and mass fragmentation patterns. In addition, the molecular ion of both adducts had an $m / z$ that 
corresponded to the addition of the molecular masses of the phenol and the aldehyde

227 involved. However, some coupling constants in the ${ }^{1} \mathrm{H}$ NMR spectra and fragment intensities in MS were different for the two adducts (see Material and Methods section). These results indicated that both, the reaction was produced by reacting one molecule of phenol with one molecule of aldehyde, and the two adducts formed had similar structures. Their structures were determined by using 1D and 2D NMR experiments. The ${ }^{1} \mathrm{H}$ NMR spectra showed that only two of the phenolic carbons and one of the hydroxyl groups remained unreacted in the phenolic part of the adducts after the reaction. In addition, the carbonyl group and the $\alpha, \beta$ carbon-carbon double bond of the aldehyde were not present in the adduct, but the $\gamma, \delta$-unsaturation remained unchanged. Furthermore, obtained spectra showed that the reaction produced a six-membered ring involving the hydroxyl group and its contiguous carbon of the 2-methylresorcinol, and the carbonyl carbon and the $\alpha, \beta$ carbon-carbon double bond of the aldehyde. HMQC and HMBC experiments allowed the unequivocal assignation of the produced structures. Thus, each adduct was produced as a mixture of diastereomers because two chiral centers were created in the reaction: carbons C2 and C4 in the adducts. Both diastereomers mostly differed in the coupling constants of the involved chiral centers. Thus, the first adducts (compounds $\mathbf{1}, \mathbf{3}$, and 5 ) had $J_{2,3 \mathrm{a}} \approx 2.6 \mathrm{~Hz}, J_{2,3 \mathrm{~b}} \approx 2.6 \mathrm{~Hz}, J_{3 \mathrm{a}, 4} \approx$ $12.1 \mathrm{~Hz}$, and $J_{3 \mathrm{~b}, 4} \approx 5.6 \mathrm{~Hz}$. The coupling constants of the second adducts (compounds 2, 4, and 6) were more difficult to determine because proton $\mathrm{H} 4$ appeared as a broad quartet in these diastereomers. Their approximate coupling constants were $J_{2,3 \mathrm{a}} \approx 2.9$

$247 \mathrm{~Hz}, J_{2,3 \mathrm{~b}} \approx 6.2 \mathrm{~Hz}, J_{3 \mathrm{a}, 4} \approx 6.4 \mathrm{~Hz}$, and $J_{3 \mathrm{~b}, 4} \approx 7 \mathrm{~Hz}$. The differences observed in these coupling constants confirmed the different spatial distribution of the involved atoms. These differences between both adducts were also observed in the relative intensities of mass fragments. Thus, for example, the molecular ion of the first adducts (compounds 
1, 3, and 5) was almost inexistent ( $0.2-1 \%$ of the base peak), but the molecular ion of

252 the second adducts (compounds 2, 4, and 6) had a relatively high intensity (12-35\% of 253 the base peak).

3.2. Effect of reaction conditions on the formation of carbonyl-phenol adducts in the reaction of 2,4-heptadienal and 2-methylresorcinol

Formation of adducts between alkadienals and 2-methylresorcinol depended on the reaction conditions, including $\mathrm{pH}$, amount of reactants, time and temperature. Fig. 2 shows the effect of $\mathrm{pH}$ value on the disappearance of 2-methylresorcinol (Fig. 2A) and on the formation of adducts 1 and $\mathbf{2}$ (Fig. 2B). As observed in the figure, the amount of 2-methylresorcinol decreased slightly between pH 6 and pH 7. However, it decreased rapidly at higher $\mathrm{pH}$ values and 2-methylresorcinol was mainly absent at $\mathrm{pH} 10$. This disappearance of the phenolic was correlated $(\mathrm{r}<-0.98, p<0.005)$ with the appearance of the adducts. Thus, adducts were mostly not produced at pH 6-7 and, then, their concentration increased linearly between $\mathrm{pH} 7$ and 10. Both adducts exhibited an analogous behavior, but adduct $\mathbf{1}$ was produced to a higher extent than adduct $\mathbf{2}$ (adduct 1/adduct 2 ratio was about 2, and this ratio was mostly constant at the different assayed $\mathrm{pH}$ values and the different reactions conditions tested).

The amount of produced adducts depended on the concentration on both 2methylresorcinol and 2,4-heptadienal. Fig. 3 shows the effect of increasing concentrations of 2-methylresorcinol on both the remaining 2-methylresorcinol at the end of the incubation (Fig. 3A) and the produced adducts (Fig. 3B). Reaction mixtures were incubated at two $\mathrm{pH}$ values: 8 and 10. At $\mathrm{pH}$, the remaining 2-methylresorcinol

273 mostly remained unchanged between 10 and $30 \mu \mathrm{mol}$ of 2-methylresorcinol and, then, 274 increased as a function of the amount of 2-methylresorcinol added (Fig. 3A). On the 275 contrary, when reaction mixtures were incubated at $\mathrm{pH}$ 10, 2-methylresorcinol was 
mostly absent at the end of the incubation period, more likely because, in addition to its

277 reaction with the aldehyde, it decomposition was preferred. Differently to 2-

methylresorcinol, adduct concentration increased when concentration of 2-

methylresorcinol increased at the two assayed $\mathrm{pH}$ values. This increase was linear at $\mathrm{pH}$

2808 between 0 and $50 \mu \mathrm{mol}$ of 2-methylresorcinol ( $\mathrm{r}>0.97, p<0.001)$, and also at $\mathrm{pH} 10$

between 10 and $50 \mu \mathrm{mol}$ of 2-methylresorcinol ( $\mathrm{r}>0.997, p<0.0002)$.

Differently to the observed when increasing amounts of 2-methylresorcinol were added, increasing amounts of 2,4-heptadienal did not cause substantial increase of amounts of adducts or decrease of amounts of 2-methylresorcinol at the different concentrations of the added aldehyde (Fig. 4). As observed in Fig. 4A, at pH 8, increasing amounts of 2,4-heptadienal produced decreasing amounts of 2methylresorcinol in the range $0-30 \mu \mathrm{mol}$ of 2,4-heptadienal, but then, the amount of remaining 2-methylresorcinol did not change significantly $(p<0.05)$. At $\mathrm{pH} 10$, addition of any amount of 2,4-heptadienal produced the complete disappearance of 2methylresorcinol. Addition of 2,4-heptadienal also produced the formation of the adducts, but this increase was not lineal (Fig. 4B). Thus, additions of a small amounts

$292(10-20 \mu \mathrm{mol})$ of 2,4-heptadienal produced high amounts of the adducts. However, additions of more than $20 \mu \mathrm{mol}$ of 2,4-heptadienal did not produce any significant 294 increase in the concentration of the adducts. temperature. 2-Methylresorcinol disappeared linearly as a function of time between 25 and $80{ }^{\circ} \mathrm{C}$ (Fig. S-1). Disappearance rates at the different temperatures were calculated by using the equation: 
where $k$ is the rate constant and $t$ is the time. Rate constants were used in an Arrhenius

301 plot to calculate the activation energy $\left(E_{\mathrm{a}}\right)$ for this disappearance. Fig. S-2 shows the obtained plot. The corresponding $E_{a}$ was obtained from the slope of the line of best fit. The $E_{\text {a }}$ determined was $46.5 \pm 5.3 \mathrm{~kJ} \cdot \mathrm{mol}^{-1}$.

304 Analogously, adduct formation increased linearly as a function of time between 25 305 and $80{ }^{\circ} \mathrm{C}$ (Fig. 5). Formation rates were also determined at the different temperatures 306 by using the equation:

$307 \quad$ [adduct] $=k t$

308 where $k$ is the rate constant and $t$ is the time. Rate constants were used in an Arrhenius 309 plot to calculate the activation energy ( $\left.E_{\mathrm{a}}\right)$ of adduct formation (Fig. S-2). The $E_{\mathrm{a}}$

310 determined from the slopes of the lines of best fit were $63.5 \pm 3.4 \mathrm{~kJ} \cdot \mathrm{mol}^{-1}$ for adduct 1 311 and $60.7 \pm 3.0 \mathrm{~kJ} \cdot \mathrm{mol}^{-1}$ for adduct 2 .

\section{Discussion}

Previous studies have shown that phenolics are able to trap a wide range of lipid oxidation products (Zamora \& Hidalgo, 2018). 2,4-Alkadienals are not an exception and they are also easily trapped by phenolics. The produced reaction implies the deactivation of the carbonyl group and the disappearance of the $\alpha, \beta$ carbon-carbon-

318 double bond of the aldehyde, which should decrease the reactivity of these compounds.

319 The reaction pathway can be suggested to take place as shown in Fig. 6. The first step would be the addition of the aromatic carbon to the $\alpha, \beta$ carbon-carbon-double bond of

321 the aldehyde. This step produces an adduct with a chiral carbon, which is later stabilized by formation of the corresponding hemiacetal between the hydroxyl and the carbonyl groups. This stabilization is responsible for the formation of the second chiral carbon. 
324 To avoid that these reactions can be reversed or the adduct can suffer further reactions

325 (including its racemization), the structure of the produced adducts was stabilized by 326 acetylation.

327 Reaction pathway described in Fig. 6 is quite similar to that described for other $\alpha, \beta$ 328 unsaturated carbonyl compounds such as 2-alkenals (Hidalgo \& Zamora, 2014) and 4329 oxo-2-alkenals (Hidalgo et al, 2018). The only difference is that the addition of the 330 hydroxyl group of the phenolics to the carbon-carbon double bond of the aldehyde, 331 previously observed for 2-alkenals and 4-oxo-2-alkenals, was not observed for 2,4332 alkadienals. This behavior might be related to the extended conjugation existing in these 333 last aldehydes. In addition, the reaction is produced in the $\alpha, \beta$ carbon-carbon double 334 bond of 2,4-alkadienals and not in the $\gamma, \delta$ unsaturation. This might be a consequence of 335 a later stabilization of the firstly produced adduct by formation of a hemiacetal. This stabilization cannot be produced when the reaction takes place at the $\gamma, \delta$ carbon-carbon double bond. Although it has not been observed, the addition to the $\gamma, \delta$ carbon-carbon

338 double bond might also be occurring but either the reaction is reversed because of the

339 lack of the stabilization of the formed adduct or the formed adduct suffers further 340 reactions because it has a free carbonyl group. These reactions might be involved in the 341 browning development observed in these reactions (data not shown), which could be a 342 consequence of polymerizations.

343 Adducts were always produced as a mixture of diastereomers because two chiral 344 centers were created. Because of the presence of the benzene ring in the adducts and the existence of large substituents (acetyl and alkenyl groups), the ideal half-chair conformations of the six-membered ring were distorted. The most favored conformation

347 for the different diastereomers were calculated by employing Chem3D (CambridgeSoft 348 Corporation, PerkinElmer Inc., Waltham, MA). Fig. S-3 shows the Newman projections 
determined for C2-C3 and C4-C3 bonds of diastereomer 2R,4S. As can be observed

350 proton $\mathrm{H} 2$ has an angle of about $60^{\circ}$ with both protons H3a and H3b. This suggests that

$351 J_{2,3 a}$ should be similar to $J_{2,3 b}$, and its value should be small according to Karplus

352

353

354

355

356

357

358

360

361

362

363

364

365

366

367

368

369

370

371

372

373 equation (Haasnoot, De Leeuw, \& Altona, 1980). This is in agreement with the observed for isomers $\mathbf{1}, \mathbf{3}$, and $\mathbf{5}$. As described above, $J_{2,3 \mathrm{a}}=J_{2,3 \mathrm{~b}} \approx 2.6 \mathrm{~Hz}$. In addition, the projection of C4 shows that $J_{3 \mathrm{~b}, 4}$ is smaller than $60^{\circ}$ and $J_{3 \mathrm{a}, 4}$ is smaller than $180^{\circ}$. This would also be in agreement with the observed coupling constants of 5.6 and 12.1 $\mathrm{Hz}$, respectively. According to these results, adducts 1, 3, and 5 should be the mixture of diastereomers $2 R, 4 S$ plus $2 S, 4 R$. Differently to these adducts, the assignment of the other pair of diastereomers (adducts $\mathbf{2 , 4}$, and $\mathbf{6}$ ) could not be achieved because proton H4 always appeared as a broad quartet and coupling constants could not be determined with accuracy. Nevertheless, these adducts should correspond to the mixture of diastereomers $2 R, 4 R$ plus $2 S, 4 S$.

Both pairs of diastereomers were not produced to the same extent. Obtained results showed that adduct $\mathbf{1}$ /adduct $\mathbf{2}$ ratio was $\sim 2$ under the different reaction conditions assayed (similar results were also obtained for the other studied adducts). This suggests that stability of adduct $\mathbf{1}$ should be higher than stability of adduct 2, most likely because of the spatial distribution of the different groups.

Adducts were produced under different reaction conditions, although some of them favored their formation more than other reaction conditions. Thus, adducts were produced to a small extent at neutral $\mathrm{pH}$, but their yields increased rapidly to higher $\mathrm{pH}$ values. This behavior is likely related to the increase of nucleophilicity of phenolic carbons, also observed in the reaction of phenolics with other aldehydes (Zamora et al., 2017). This high nucleophilicity is needed for the first step of the reaction pathway proposed in Fig. 6. In addition, adduct formation also increased as a function of time 
and temperature between 25 and $80{ }^{\circ} \mathrm{C}$, which is in agreement with the $E_{\text {a }}$ determined

375 for adduct formation $\left(E_{\mathrm{a}} 60.7-63.5 \mathrm{~kJ} \cdot \mathrm{mol}^{-1}\right)$. However, when samples were heated to a much higher temperature, adducts could not be isolated (data not shown). This is likely a consequence of the decomposition observed for 2,4-alkadienals at a high temperature and in the presence of aqueous solvents (Zamora et al., 2015). These results suggest that, different to carbonyl-phenol adducts derived from 2-alkenals which have been detected in fried foods (Zamora et al., 2016), carbonyl-phenol adducts derived from 2,4alkadienals should be expected to be present in foods submitted to a softer heating.

All above results confirm that phenolic compounds are able to trap a wide array of lipid oxidation products, including, alkanals, 2-alkenals, 4-oxo-2-alkenals, 4,5-epoxy-2alkenals, and also 2,4-alkadienals. The reaction always produces the modification and, therefore, the deactivation of the most reactive groups of the carbonyl compounds. Thus, it produces the disappearance of: the carbonyl group in alkanals; the carbonyl group and the conjugated carbon-carbon double bond in 2-alkenals; the carbonyl group and the $\alpha, \beta$ carbon-carbon double bond in 2,4-alkadienals; one of the carbonyl groups and the conjugated carbon-carbon double bond in 4-oxo-2-alkenals; and the epoxy, the carbonyl group and the conjugated carbon-carbon double bond in 4,5-epoxy-2-alkenals.

391 Although the disappearance of the carbonyl group cannot be considered complete because, in most cases, it is forming part of a hemiacetal that can be easily reversed and

393 the carbonyl group recovered, this reaction decreases the reactivity of the carbonyl

394 compound towards other nucleophiles. Thus, for example, phenolics have been shown to protect amino acids from degradation caused by carbonyl compounds by effective carbonyl trapping (Hidalgo, Delgado, \& Zamora, 2017). The above described results provide the basis for the detection of the carbonyl-phenol adducts derived from 2,4398 alkadienals in food products. 
400 The authors declare no conflicts of interest.

\section{Acknowledgments}

402 We are indebted to José L. Navarro for technical assistance. This study was

403 supported in part by the European Union (FEDER funds) and the Plan Nacional de I + 404 D of the Ministerio de Economía y Competitividad of Spain (project AGL2015-68186$405 \mathrm{R})$.

406 Appendix A. Supplementary data

407 Supplementary data associated with this article can be found, in the online version, at 
409 Bastos, L. C. S., Costa, E. A. D., \& Pereira, P. A. P. (2017) Development, validation 410 and application of an UFLC-DAD-ESI-MS method for determination of carbonyl 411 compounds in soybean oil during continuous heating. Food Chemistry, 218, 518412524

413 Chen, H. J., Cao, P. R., Li, B., Sun, D. W., Wang, Y., Li, J. W., \& Liu, Y. F. (2017).

414 Effect of water content on thermal oxidation of oleic acid investigated by

415 combination of EPR spectroscopy and SPME-GC-MS/MS. Food Chemistry, 221, $416 \quad 1434-1441$.

417 Concepcion, J. C. T., Ouk, S., Riedel, A., Calingacion, M., Zhao, D., Ouk, M., Garson, 418 M. J., \& Fitzgerald, M. A. (2018). Quality evaluation, fatty acid analysis and 419 untargeted profiling of volatiles in Cambodian rice. Food Chemistry, 240, 1014$420 \quad 1021$.

421 Haasnoot, C. A. G., De Leeuw, F. A. A. M., \& Altona, C. (1980). The relationship 422 between proton-proton NMR coupling constants and substituent electronegativities. 423 I. An empirical generalization of the Karplus equation. Tetrahedron, 36, 2783-2792. 424 Hidalgo, F. J., \& Zamora, R. (2014). 2-Alkenal-scavenging ability of m-diphenols. Food 425 Chemistry, 160, 118-126.

426 Hidalgo, F. J., Aguilar, I., \& Zamora, R. (2017). Model studies on the effect of aldehyde 427 structure on their selective trapping by phenolic compounds. Journal of Agricultural 428 and Food Chemistry, 65, 4736-4743.

429 Hidalgo, F. J., Aguilar, I., \& Zamora, R. (2018). Phenolic-trapping of lipid oxidation 430 products 4-oxo-2-alkenals. Food Chemistry, 240, 822-830 
Hidalgo, F. J., Delgado, R. M., \& Zamora, R. (2009). Degradation of asparagine to acrylamide by carbonyl-amine reactions initiated by alkadienals. Food Chemistry, 116, 779-784.

Hidalgo, F. J., Delgado, R. M., \& Zamora, R. (2017). Protective effect of phenolic compounds on carbonyl-amine reactions produced by lipid-derived reactive carbonyls. Food Chemistry, 229, 388-395.

Hidalgo, F. J., Navarro, J. L., \& Zamora, R. (2018). Structure-activity relationship (SAR) of phenolics for 2-amino-1-methyl-6-phenylimidazo[4,5-b]pyridine (PhIP) formation in phenylalanine/creatinine reaction mixtures including (or not) oxygen and lipid hydroperoxides. Journal of Agricultural and Food Chemistry, 66, 255-264.

Hidalgo, F. J., Navarro, J. L., Delgado, R. M., \& Zamora, R. (2013). Histamine formation by lipid oxidation products. Food Research International, 52, 2016-213.

Lorenzo, J. M., Pateiro, M., Fontan, M. C. G., \& Carballo, J. (2014). Effect of fat content on physical, microbial, lipid and protein changes during chill storage of foal liver pate. Food Chemistry, 155, 57-63.

Potes, N., Kerry, J. P., \& Roos, Y. H. (2013). Oil as reaction medium for glycation, oxidation, denaturation, and aggregation of whey protein systems of low water activity. Journal of Agricultural and Food Chemistry, 61, 3748-3756.

Rendon, M. Y., Salva, T. D. G., \& Bragagnolo, N. (2014). Impact of chemical changes on the sensory characteristics of coffee beans during storage. Food Chemistry, 147, 279-286.

Salazar, R., Arambula-Villa, G., Hidalgo, F. J., \& Zamora, R. (2014). Structural characteristics that determine the inhibitory role of phenolic compounds on 2-amino- 

1-methyl-6-phenylimidazo[4,5-b]pyridine (PhIP) formation. Food Chemistry, 151, 480-486.

456

Snedecor, G. W., \& Cochran, W. G. (1980). Statistical methods (7th ed.). Ames: IA:

457 Iowa State University Press.

Zamora, R., \& Hidalgo, F. J. (2005). Coordinate contribution of lipid oxidation and 459 Maillard reaction to the nonenzymatic food browning. Critical Reviews in Food Science and Nutrition, 45, 49-59.

Zamora, R., \& Hidalgo, F. J. (2016). The triple defensive barrier of phenolic compounds against the lipid oxidation-induced damage in food products. Trends in Food Science \& Technology, 54, 165-174.

Zamora, R., \& Hidalgo, F. J. (2018). Carbonyl-phenol adducts - An alternative sink for 465 reactive and potentially toxic lipid oxidation products. Journal of Agricultural and Food Chemistry, 66, 1320-1324.

Zamora, R., Aguilar, I., \& Hidalgo, F. J. (2017). Epoxyalkenal-trapping ability of 468 phenolic compounds. Food Chemistry, 137, 444-452

Zamora, R., Aguilar, I., Granvogl, M., \& Hidalgo, F. J. (2016). Toxicologically relevant aldehydes produced during the frying process are trapped by food phenolics. Journal of Agricultural and Food Chemistry, 64, 5583-5589.

Zamora, R., Alcon, E., \& Hidalgo, F. J. (2012). Effect of lipid oxidation products on the formation of 2-amino-1-methyl-6-phenylimidazo[4,5-b]pyridine (PhIP) in model systems. Food Chemistry, 135, 2569-2574.

Zamora, R., Gallardo, E., \& Hidalgo, F. J. (2007). Strecker degradation of phenylalanine initiated by 2,4-decadienal or methyl 13-oxooctadeca-9,11-dienoate in model systems. Journal of Agricultural and Food Chemistry, 55, 1308-1314. 
478 Zamora, R., Navarro, J. L., Aguilar, I., \& Hidalgo, F. J. (2015). Lipid-derived aldehyde 479 degradation under thermal conditions. Food Chemistry, 174, 89-96. 

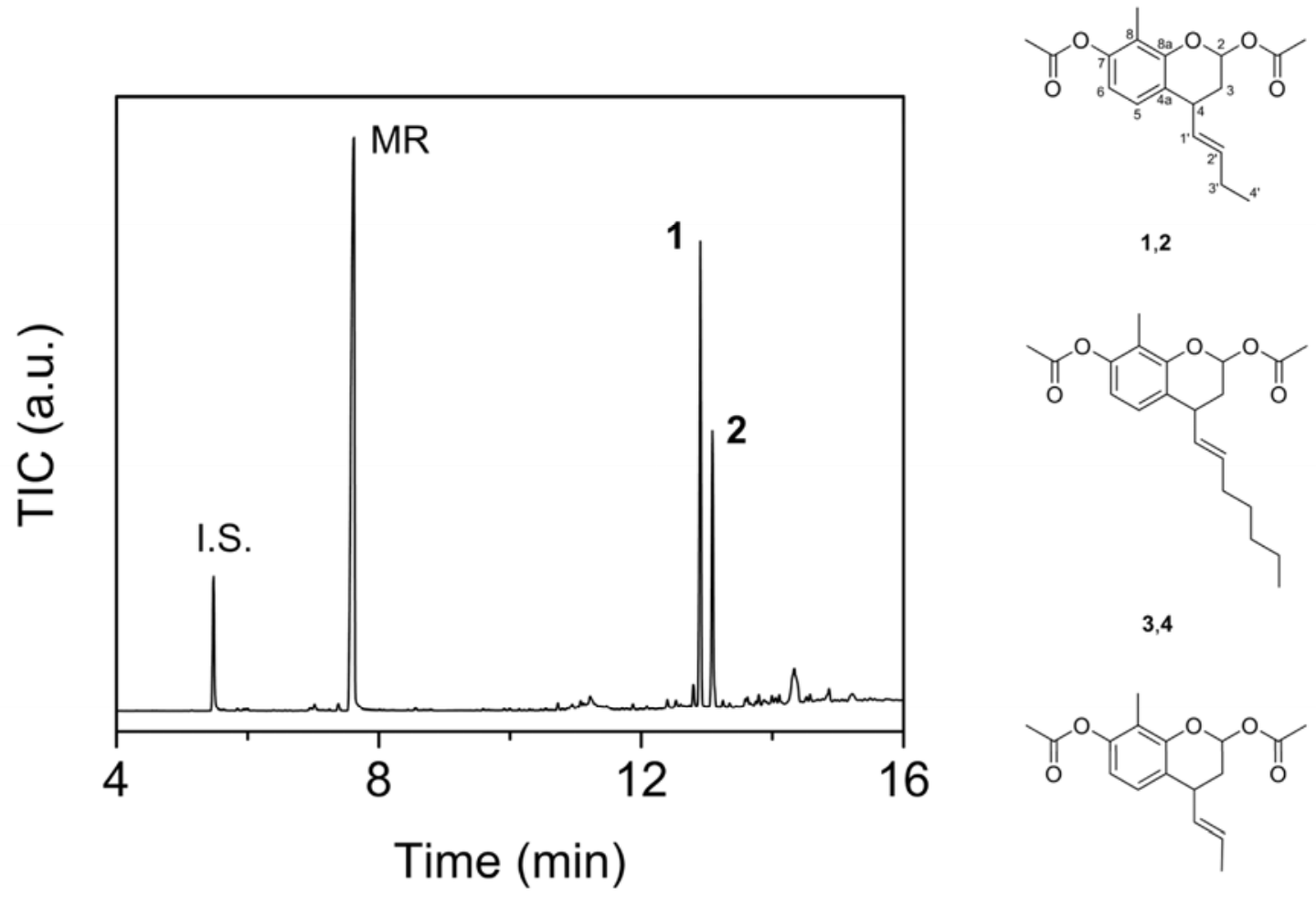

3,4

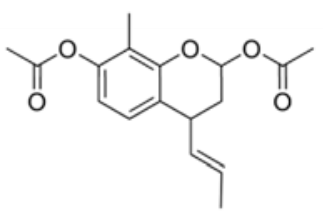

5,6

Fig. 1. Total ion chromatogram (TIC) of the reaction between 2,4-heptadienal and 2methylresorcinol (MR) after $20 \mathrm{~h}$ at $60^{\circ} \mathrm{C}$ and later acetylation. Formed adducts are identified as compounds $\mathbf{1}$ and $\mathbf{2}$. Structures for these adducts and the adducts formed in the other studied reactions are also shown. I.S. corresponds to the peak of the internal standard. 


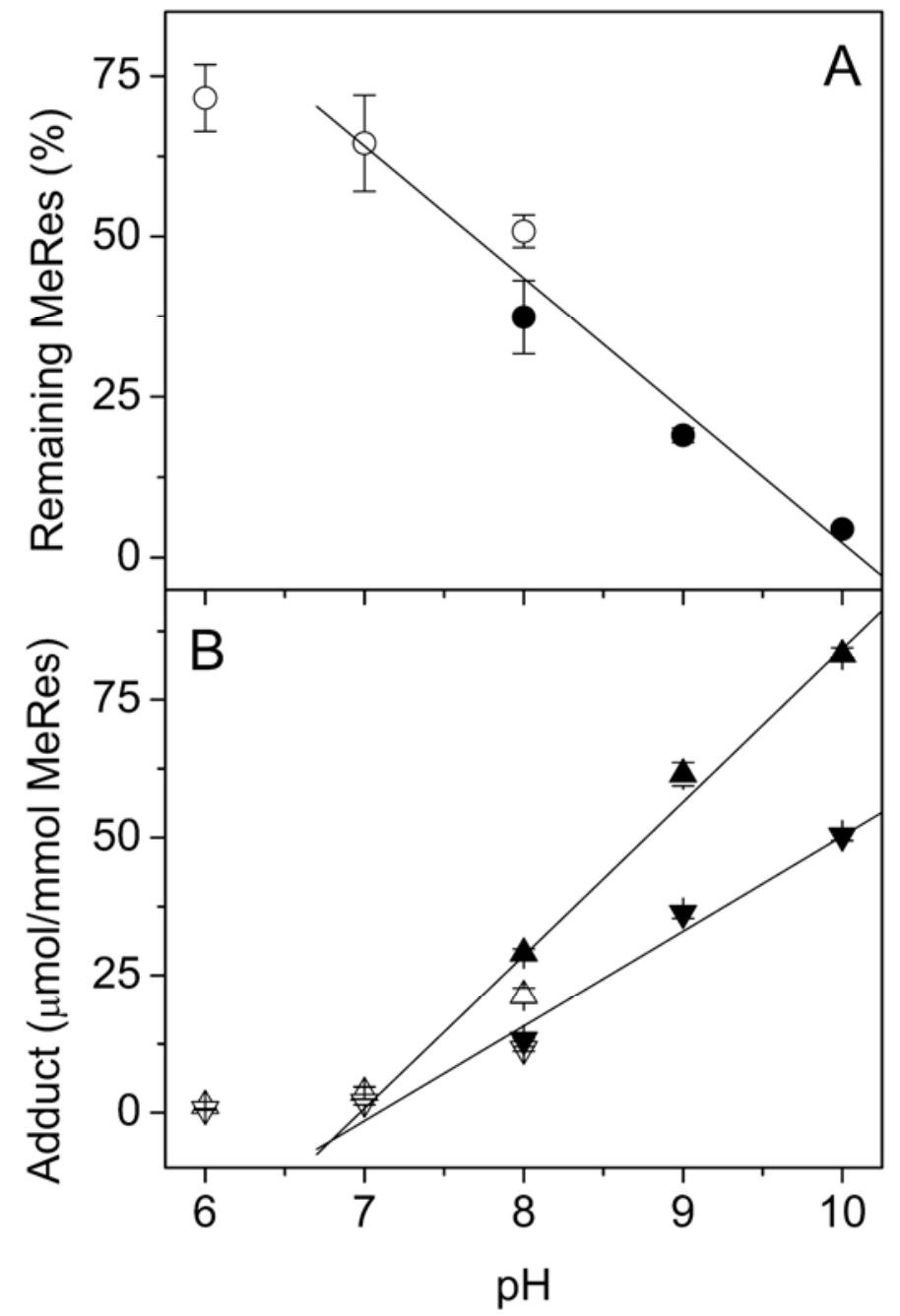

Fig. 2. Effect of reaction pH on: A, 2-methylresorcinol (MeRes) disappearance; and B, carbonyl-phenol formation, in the reaction between 2-methylresorcinol and 2,4heptadienal after $20 \mathrm{~h}$ at $60{ }^{\circ} \mathrm{C}$. Assayed buffers were $0.3 \mathrm{M}$ sodium phosphate (open symbols) and $0.3 \mathrm{M}$ sodium borate (closed symbols). Determined compounds were 2methylresorcinol $(\bigcirc, \boldsymbol{\bullet})$, adduct $\mathbf{1}(\triangle, \mathbf{\Delta})$, and adduct $\mathbf{2}(\nabla, \boldsymbol{\nabla})$. 


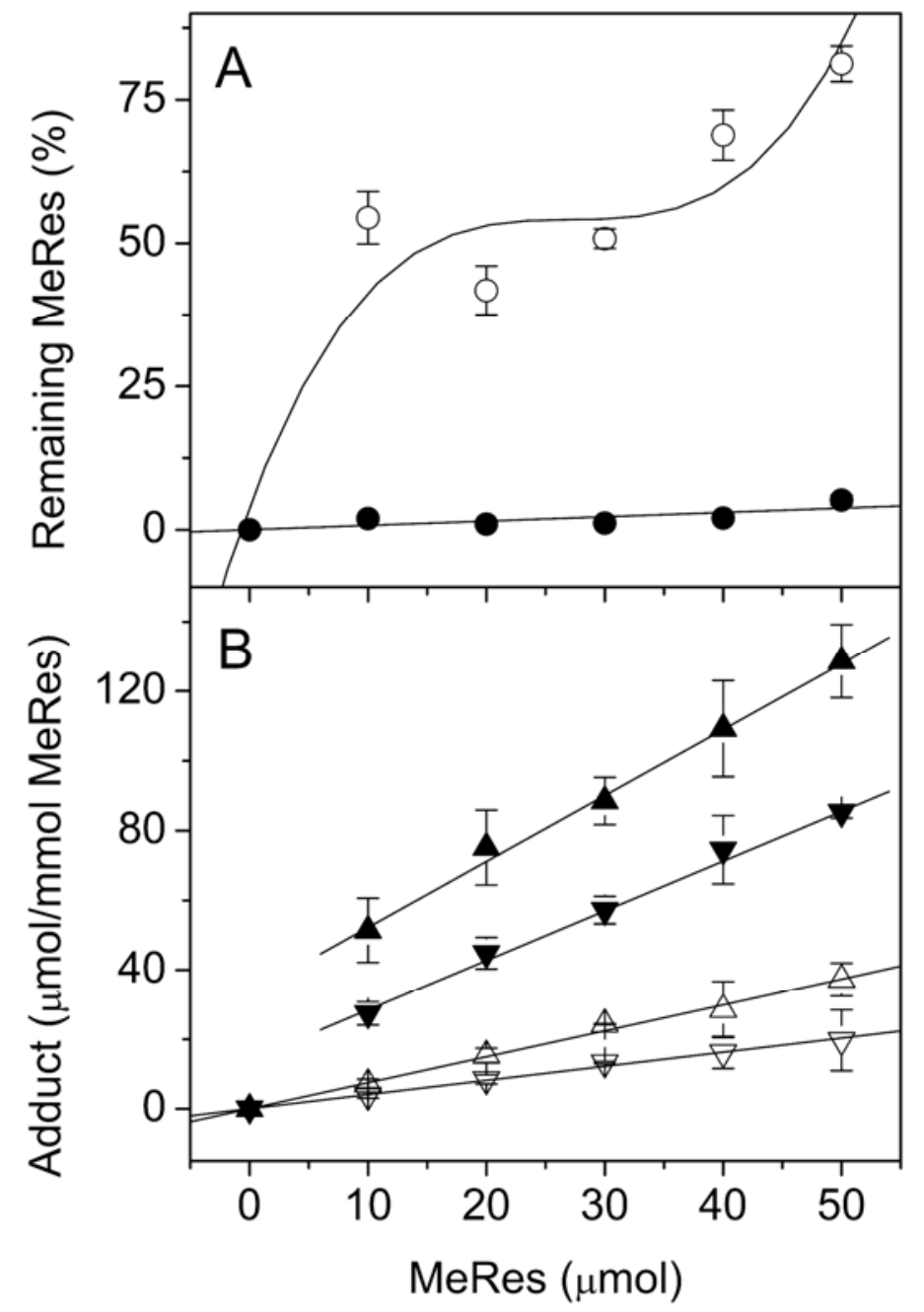

Fig. 3. Effect of the concentration of 2-methylresorcinol (MeRes) on: A, 2methylresorcinol disappearance; and B, carbonyl-phenol formation, in the reaction between 2-methylresorcinol and 2,4-heptadienal in $0.3 \mathrm{M}$ sodium phosphate, $\mathrm{pH} 8$ (open symbols), and $0.3 \mathrm{M}$ sodium borate, $\mathrm{pH} 10$ (closed symbols), after $20 \mathrm{~h}$ at $60{ }^{\circ} \mathrm{C}$. Determined compounds were 2-methylresorcinol $(\bigcirc, \boldsymbol{\bullet})$, adduct $\mathbf{1}(\triangle, \boldsymbol{\Delta})$, and adduct $\mathbf{2}$ $(\nabla, \nabla)$ 


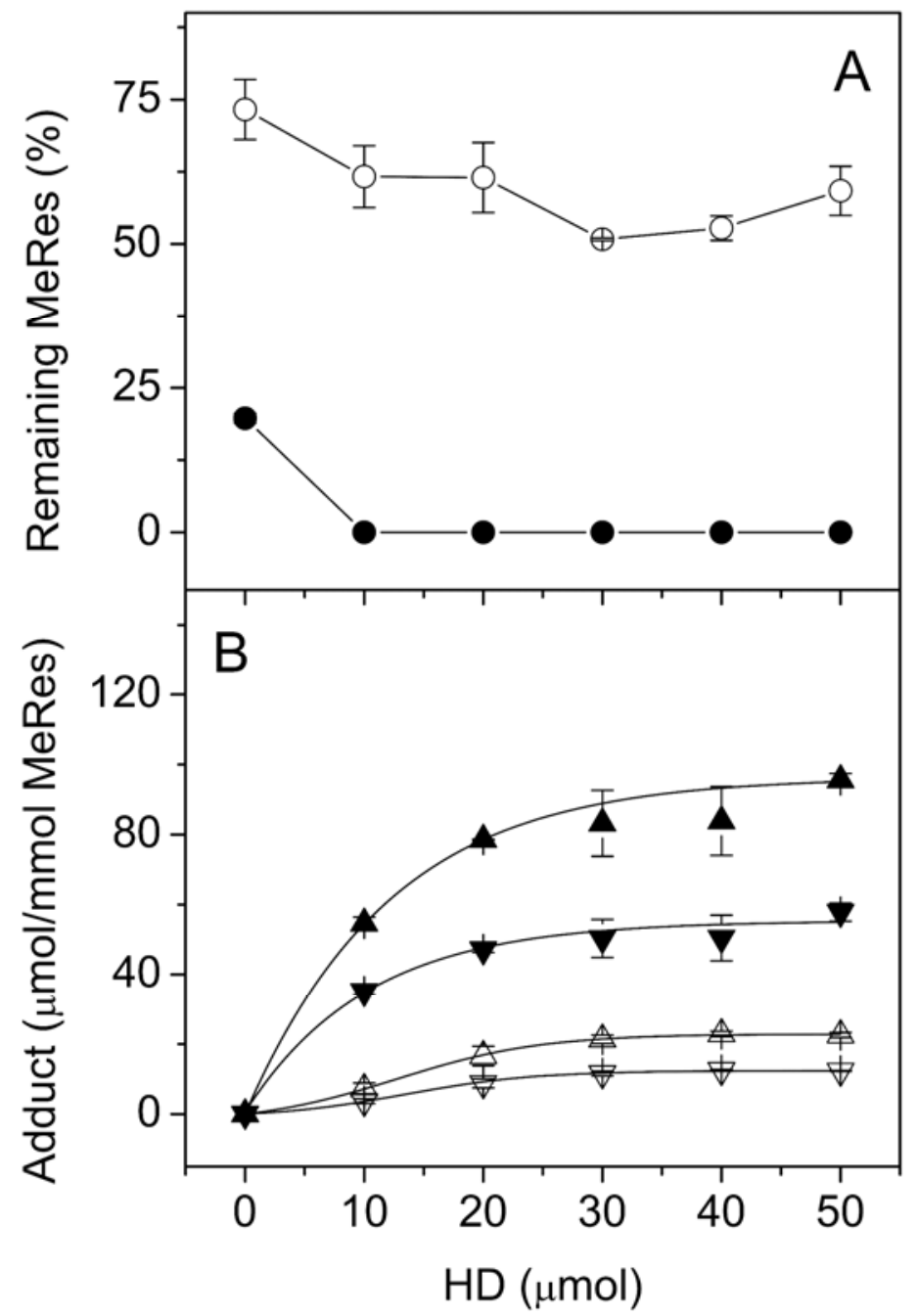

Fig. 4. Effect of the concentration of 2,4-heptadienal on: A, 2-methylresorcinol (MeRes) disappearance; and B, carbonyl-phenol formation, in the reaction between 2methylresorcinol and 2,4-heptadienal in $0.3 \mathrm{M}$ sodium phosphate, $\mathrm{pH} 8$ (open symbols), and $0.3 \mathrm{M}$ sodium borate, $\mathrm{pH} 10$ (closed symbols), after $20 \mathrm{~h}$ at $60{ }^{\circ} \mathrm{C}$. Determined compounds were 2-methylresorcinol $(\bigcirc, \boldsymbol{\Theta})$, adduct $\mathbf{1}(\triangle, \mathbf{\Delta})$, and adduct $\mathbf{2}(\nabla, \boldsymbol{\nabla})$. 


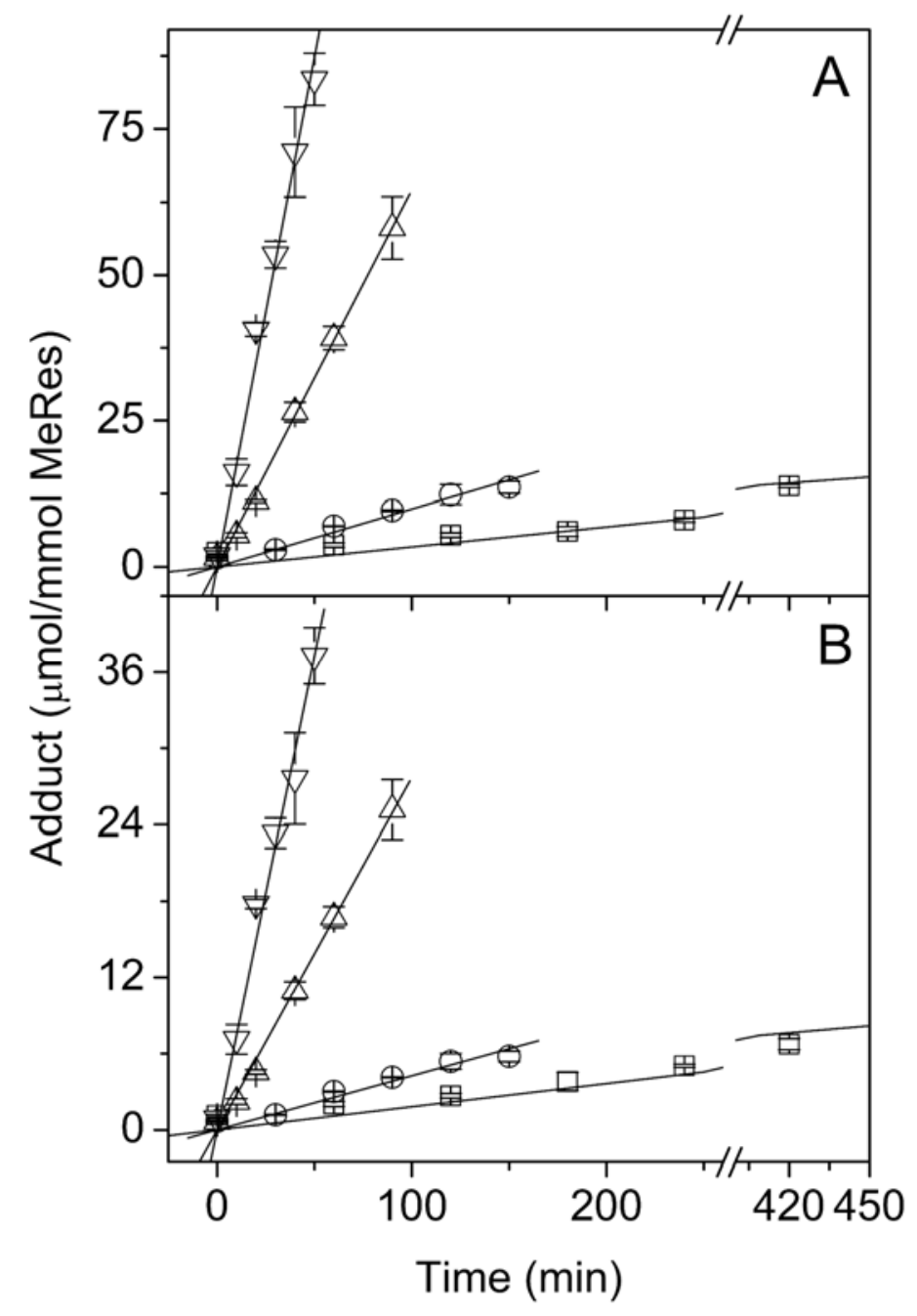

Fig. 5. Time-course of the formation of: A, adduct $\mathbf{1}$; and B, adduct $\mathbf{2}$, in the reaction between 2-methylresorcinol (MeRes) and 2,4-heptadienal in $0.3 \mathrm{M}$ sodium borate, $\mathrm{pH}$ 10). Assayed temperatures were: $25(\square), 37(\bigcirc), 60(\triangle)$, and $80{ }^{\circ} \mathrm{C}(\nabla)$. 
<smiles>Cc1c(O)cccc1O</smiles><smiles>[R]C=CC=CC=O</smiles><smiles>[R]C=CC(CC=O)c1ccc(O)c(C)c1O</smiles><smiles>[R]C=CC1CC(OC(C)=O)Oc2c1ccc(OC(C)=O)c2C</smiles>

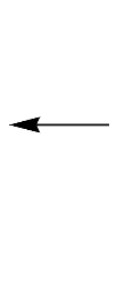<smiles>[R]C=CC1CC(O)Oc2c1ccc(O)c2C</smiles>

Fig. 6. Proposed reaction pathway for the formation of carbonyl-phenol adducts in the reaction between 2-methylresorcinol and 2,4-alkadienals. 


\section{Supplementary Figures}

\section{2,4-Alkadienal trapping by phenolics}

Francisco J. Hidalgo and Rosario Zamora *

Instituto de la Grasa, Consejo Superior de Investigaciones Científicas, Carretera de Utrera km 1, Campus Universitario - Edificio 46, 41013-Seville, Spain

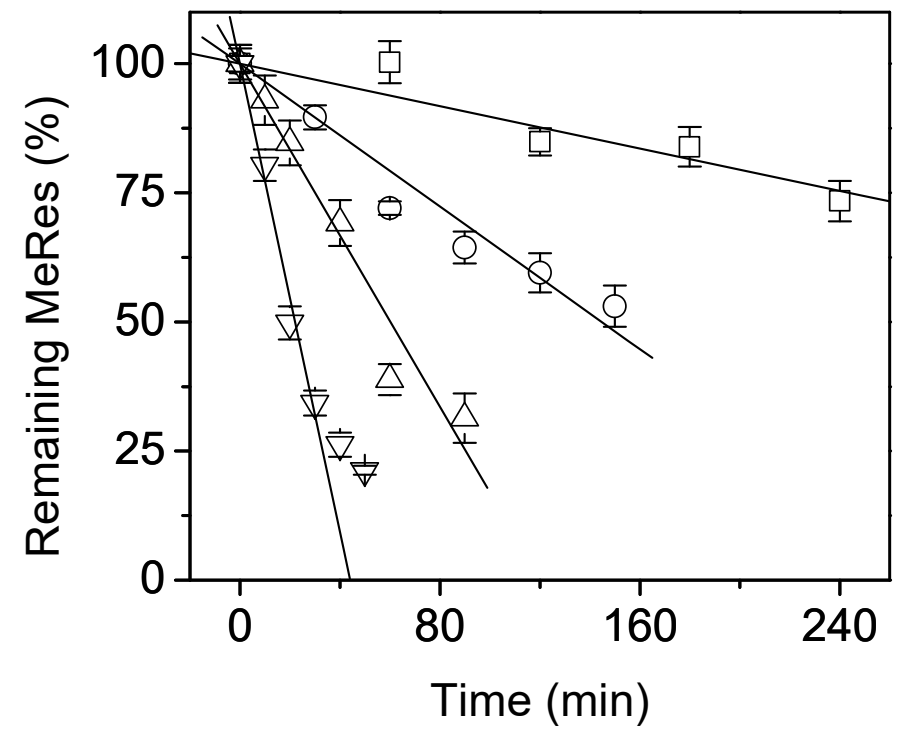

Fig. S-1. Time-course of 2-methylresorcinol (MeRes) disappearance in the reaction between 2-methylresorcinol and 2,4-heptadienal in $0.3 \mathrm{M}$ sodium borate, $\mathrm{pH} 10$. Assayed temperatures were: $25(\square), 37(\bigcirc), 60(\triangle)$, and $80^{\circ} \mathrm{C}(\nabla)$. 


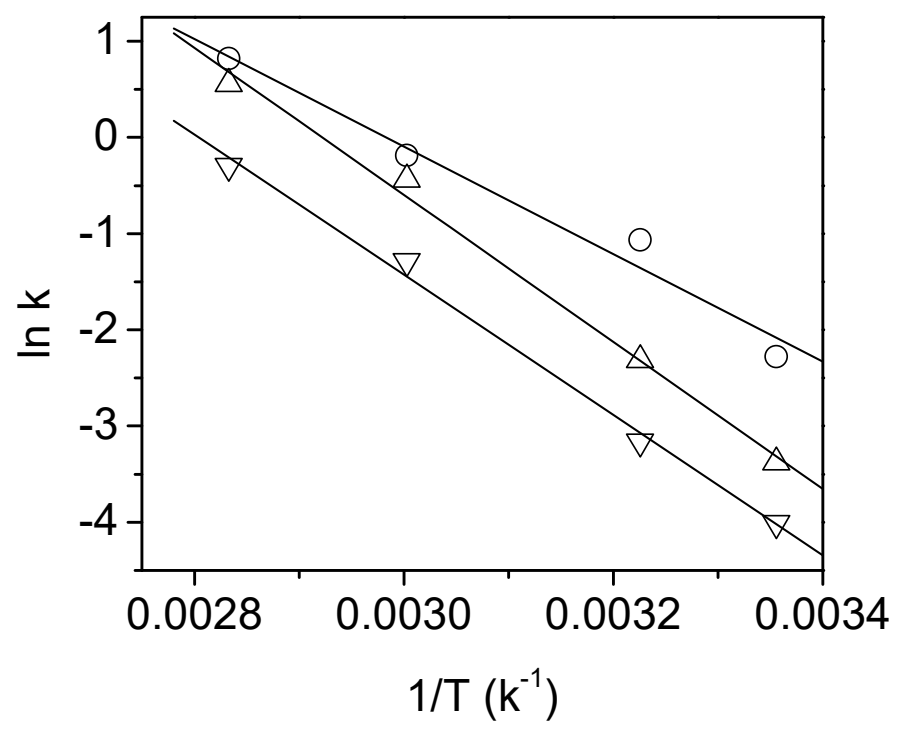

Fig. S-2. Arrhenius plot for 2-methylresorcinol disappearance $(\bigcirc)$ and adduct $1(\triangle)$ and adduct $2(\nabla)$ formation in the reaction between 2-methylresorcinol and 2,4heptadienal.

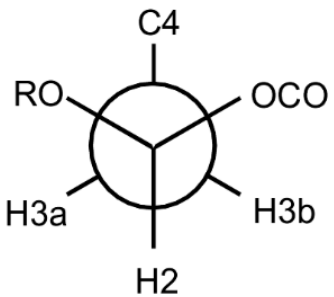

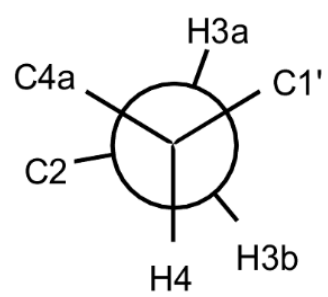

Fig. S-3. Newman projections for $\mathrm{C} 2-\mathrm{C} 3$ and $\mathrm{C} 4-\mathrm{C} 3$ bonds of diastereomer $2 R, 4 S$ of adducts $\mathbf{1}, \mathbf{3}$, and $\mathbf{5}$. These adducts were isolated as a mixture of diastereomers $2 R, 4 S$ and $2 S, 4 R$. The represented projections correspond to the most favored conformation calculated by employing Chem3D (CambridgeSoft Corporation, PerkinElmer Inc., Waltham, MA). 